\title{
Pengembangan dan Evaluasi Kurikulum Pendidikan Di Pondok Pesantren Desa Ganjaran Gondanglegi Malang
}

\author{
Yazidul Busthomi \\ Institut Agama Islam Al-Qolam Gondanglegi Malang, Indonesia \\ Email:yazidulbusthomi03@gmail.com \\ Syamsul A'dlom \\ Institut Agama Islam Al-Qolam Gondanglegi Malang, Indonesia
}

\begin{abstract}
Islamic boarding schools in the village of Malang Ganjaran Gondanglegi are Islamic educational institutions with a Salaf Islamic curriculum so far believed to be a place of religious education, proven to be one of the places where preaching education still exists. However, curriculum development and evaluation in this Islamic boarding school, there is still no data that can be ascertained, so it is interesting to study. So the researcher raised a title "development and evaluation of educational curricula in Malang Ganjaran Gondanglegi boarding school". Based on the background of the problem stated above, the problem formulation can be taken, namely: 1) How is the development of the Islamic religious education curriculum in the Islamic boarding school of Ganjaran Gondanglegi village in Malang ?. 2) What is the evaluation of the Islamic religious education curriculum in the Islamic boarding school of Ganjaran Gondanglegi village in Malang ?. This study uses a qualitative approach. Data was collected through interviews, participant observation and documentation. From the results of this study it was found that the development of the Islamic religious education curriculum in the Ganjaran village Islamic boarding school is by developing a curriculum plan with clear objectives, developing curriculum plans according to the characteristics of the santri, preparing the lesson schedule, determining the teaching materials to be taught, determining the material that must be read by santri, provide a source of teaching and learning processes, prepare prospective Islamic religious education teachers, and in the application of educational curriculum is strongly influenced by the ability of the teacher. The evaluation of the Islamic religious curriculum in the Ganjaran village boarding school was carried out twice in the development of its curriculum, using measurement instruments in the form of standard tests, teachermade tests, oral tests, and questionnaires.
\end{abstract}

Keywords: Curriculum, Education, Islamic Boarding School

\section{Pendahuluan}

Dalam sebuah lembaga pendidikan, ada lembaga formal dan non formal. Lembaga pendidikan formal sering disebut pendidikan persekolahan. Sedangkan lembaga pendidikan non formal adalah jalur pendidikan di luar pendidikan formal yang dapat dilaksanakan secara terstruktur dan berjenjang. Seperti pondok pesantren yang mana sebagai salah suatu lembaga pendidikan sebagai tempat pembelajaran non formal dalam suatu masyarakat. pondok pesantren amat penting bagi manusia, karena ia sebagai jalan dan cara untuk membangun dan mengembangkan serta mengkaji ilmu-ilmu agama. Dalam sebuah lembaga pendidikan, dalam rangka tercapainya tujuan dari proses pembelajaran, maka 
diperlukan sebuah perencanaan proses pembelajaran dalam jangka waktu tertentu. Karena itulah diperlukan sebuah kurikulum. kurikulum menggambarkan kegiatan belajar mengajar dalam suatu lembaga kependidikan tidak hanya dijabarkan serangkai ilmu pengetahuan yang harus diajarkan pendidik kepada anak didik, dan anak didik mempelajarinya. Tetapi juga segala kegiatan yang bersifat kependidikan yang dipandang perlu, karena mempunyai pengaruh terhadap anak didik dalam rangka mencapai tujuan pendidikan.

Kurikulum merupakan alat yang sangat penting dalam keberhasilan suatu pendidikan, tanpa adanya kurikulum yang baik dan tepat maka akan sulit dalam mencapai tujuan dan sasaran pendidikan yang telah dicita-citakan oleh suatu lembaga pendidikan, baik formal, informal maupun non formal. Karena segala sesuatu harus ada manajemennya bila ingin menghasilkan sesuatu yang baik, sesuai dengan yang diharapkan.

Pondok pesantren merupakan lembaga pendidikan Islam tertua yang berfungsi sebagai salah satu benteng pertahanan umat Islam, pusat dakwah dan pusat pengembangan masyarakat muslim di Indonesia. Istilah pondok pesantren pertama kali dikenal di jawa, di aceh dikenal dengan rangkah dan dayah, di Sumatra Barat dikenal dengan surau. Dimana kurikulum senantiasa mengalami perubahan, perbaikan dan pembaruan. Di Indonesia, telah tercatat dalam sejarah pendidikannya telah mengalami beberapa kali perubahan kurikulum seiring perubahan dan tuntutan kebutuhan masyarakat. Disamping kurikulum formal dan non formal, terdapat juga kurikulum tersembunyi (the hidden curriculum). Dimana kurikulum ini antara lain berupa aturan-aturan yang tidak tertulis, yang tentunya kurikulum ini bisa berkonotasi positif maupun negatif.

Apabila hal ini dikaitkan dengan pesantren sebagai lembaga pendidikan bahwa konsep kurikulum yang digunakan dalam pondok pesantren tidak hanya mengacu pada pengertian kurikulum sebagai materi semata, melainkan jauh lebih luas dari itu, yakni menyangkut keseluruhan pengalaman belajar santri yang masih berada dalam lingkup koordinasi pondok pesantren. Termasuk didalamnya sistem pendidikan dan pengajaran yang berlaku di pesantren, yang mana perlu diadakan suatu rekonstruksi sesuai dengan tuntutan masyarakat dan zaman. Sehingga misi dan cita-cita pondok pesantren dapat berperan dalam pembangunan masyarakat.

Salah satu keunikan pesantren adalah independensinya yang kuat, dimana masyarakat memiliki keleluasaan dan kebebasan relatif yang tidak harus memihak atau mengikuti model baku yang ditetapkan oleh pemerintah dalam bidang pendidikan. Pesantren bebas mengembangkan model pendidikannya tanpa harus mengikuti standarisasi dan kurikulum yang ketat. Karena cenderung pada sentralistik yang berpusat di tangan kiai. Model pendidikan seperti inilah yang berjalan di pesantren menjadi sangat beragam sesuai dengan kecenderungan dan misi yang ingin dikembangkan oleh sang kyai, yang sebagai pemimpin sekaligus sebagai pengasuh pondok pesantren.

Pendidikan pesantren biasanya lebih menekankan terhadap satu aspek disiplin keilmuan tertentu, sehingga mengabaikan aspek keilmuan lainnya. Karena pelajaran agama masih dominan di beberapa lingkungan pesantren, bahkan materinya hanya khusus disajikan dalam bentuk Bahasa Arab, dan pengetahuan 
umum dilaksanakan hanya setengah-setengah atau bahkan tidak dilaksanakan sama sekali, sehingga kemampuan santri terbatas dan masih kurang mendapat pengakuan dari sebagian masyarakat.

Pendidikan agama Islam adalah sejajar dengan mata pelajaran lain di sekolah seperti pendidikan matematika ataupun pendidikan biologi. Dalam kurikulum pendidikan agama Islam dijelaskan bahwa pendidikan agama Islam adalah upaya sadar dan terencana dalam mempersiapkan peserta didik untuk mengenal memahami menghayati hingga mengimani ajaran agama Islam bersamaan dengan tuntunan untuk menghormati penganut agama lain dalam hubungan dengan kerukunan antar umat beragama hingga terwujud persatuan dan kesatuan bangsa. Jadi kurikulum pendidikan pesantren adalah bahan-bahan pendidikan agama Islam di pesantren berupa kegiatan pengetahuan dan pengalaman yang dengan sengaja diberikan kepada santri dalam rangka mencapai tujuan pendidikan agama Islam. Kurikulum pendidikan pesantren merupakan alat untuk mencapai tujuan pendidikan agama Islam. Adapun ruang lingkup materi pendidikan pesantren secara umum adalah: Al-Qur'an, hadits dan kitab-kitab klasik. Dengan kata lain cakupan pendidikan pesantren yaitu ada keserasian, keselarasan dan keseimbangan antara hubungan manusia dengan Allah dan hubungan manusia dengan sesama manusia dan makhluk lainnya. Untuk mencapai tujuan pendidikan pesantren perlu rekonstruksi kurikulum agar lebih riil. Rumusan tujuan pendidikan pesantren yang ada selama ini masih bersifat general.

Pengembangan kurikulum pendidikan pesantren yang terus menerus menyangkut seluruh komponen merupakan sesuatu yang mutlak untuk dilakukan agar ia tak kehilangan relevansi dengan kebutuhan riil yang dihadapi komonitas pendidikan Islam yang kecenderungan terus mengalami proses dinamika transformatif. Pendidikan pesantren yang dibangun atas dasar pemikiran yang Islami bertolak dari pandangan hidup dan pandangan tentang manusia serta diarahkan kepada tujuan pendidikan yang dilandasi kaidah-kaidah Islam. keberadaan kurikulum dalam sebuah lembaga pendidikan sangat penting. Kita kadang-kadang pernah mendengar sorotan tajam bahwa kurikulum selalu tertinggal dengan perkembangan zaman. Komponen evaluasi berisi penilaian baik yang dilakukan secara terus menerus maupun bertahap dan bersifat menyeluruh terhadap bahan atau program pengajaran yang dimaksudkan sebagai umpan balik terhadap tujuan, materi, metode, sarana, dalam rangka membina dan mengembangkan kurikulum lebih lanjut.

Keunikannya kajian ini, yaitu pondok pesantren di desa Ganjaran Gondanglegi Malang merupakan lembaga pendidikan Islam dengan kurikulum Agama Islam salaf selama ini dipercaya sebagai tempat pendidikan agama, terbukti mampu menjadi salah satu tempat pendidikan dakwah yang masih eksis. Secara substansial, pondok pesantren ini merupakan institusi keagamaan yang sangat lekat dengan masyarakat, khususnya masyarakat pedesaan. Lembaga pondok pesantren tersebut tumbuh dan berkembang dari masyarakat dan untuk masyarakat dengan memposisikan dirinya sebagai bagian dari masyarakat. Pondok pesantren ini bukan hanya mendidik santri untuk dapat memahami kitabkitab klasik seperti tafsir al-Qur'an, kitab hadits, kitab akhlaq, dan kitab fiqih, 
tetapi juga mendidik santri untuk dapat berinteraksi sosisal dengan masyarakat, baik masyarakat di dalam pesantren maupun di lingkungan luar pesantren. Pondok pesantren ini juga mendidik santri untuk selalu mengabdi baik kepada kyai, guru, santri senior, maupun sesama santri yang lain. Adanya ta'dhim dan tawadhu' di dalam pesantren juga sebagai bagian dari pendididkan di pesantren, dimana hal tersebut mengajarkan santri untuk memiliki sifat rendah hati dan sopan santun dalam bermasyarakat. Namun, pengembangan kurikulum dan evaluasi di pondok pesantren ini, masih belum ada data yang dapat dipastikan, sehingga menarik untuk dikaji.

Pada zaman sekarang, ketika kehidupan manusia semakin berkembang, maka keinginan untuk menghadirkan ajaran agama yang sesuai dengan kebutuhan masyarakat menjadi suatu kebutuhan yang sangat penting yang tidak bisa dihindari lagi. Karena sebagaimana dapat diketahui betapapun istimewanya ajaran Islam yang dijelasakan al-Qur'an, ajaran tersebut tidak akan mempunyai makna luas ketika tidak mampu dijabarkan menjadi panduan operasional-fungsional yang dapat dirasakan bagi kebutuhan umat Islam. Untuk itu dibutuhkan alat penyampaian ajaran Islam yang baik dan mengena pada umat Islam, alat tersebut adalah berupa dakwah Islam dengan berbagai komponennya.

Santri pada era kontemporer ini dihadapkan pada berbagai tantangan dan masalah yang semakin kompleks. Hal tersebut tidak terlepas dari adanya perubahan dan perkembangan dinamika masyarakat yang semakin maju dan modern. Perkembangan era teknologi dan transportasi yang begitu canggih secara tidak sadar telah menggiring umat manusia pada pilihan. Satu sisi, pilihan tersebut membawa hikmah dan manfaat bagi kehidupan manusia, akan tetapi disisi lain perkembangan tersebut juga membawa dampak yang negatif.

Mengingat aktivitas santri tidak terlepas dari masyarakat, maka perkembangannya seharusnya juga mengimbangi atau berbanding lurus dengan perkembangan masyarakat, artinya aktivitas santri hendaknya dapat mengikuti perkembangan dan perubahan masyarakat, sehingga aktivitas santri tidak hanya menjadi pelengkap hidup semata akan tetapi, lebih dari itu yaitu sebagai roda dalam mengiringi perkembangan masyarakat modern sekarang. Tantangan santri yang begitu kompleks pada masa sekarang ini menuntut para santri untuk tidak sekedar menguasai materi fiqih dan akhlaq saja, akan tetapi lebih dari pada itu, santri dituntun juga harus dapat mengetahui perubahan dan kebutuhan masyarakat, artinya santri harus mampu membawa masyarakat pada garis nilai-nilai ajaran Islam tanpa mengesampingkan kebutuhan masyarakat pada teknologi kemajauan zaman. Untuk itu penting kiranya santri untuk memiliki pendidikan yang unggul dan dapat diandalkan dalam berdakwah nantinya. Pendidikan yang di butuhkan oleh para santri adalah bukan sekedar pendidikan keagamaan atau keIslaman semata, akan tetapi lebih dari pada itu adalah pedidikan yang berfokus dalam dakwah beserta ilmunya, atau biasa disebut sebagai pendidikan santri, yaitu pendidikan yang difokuskan pada bidang akhlaq mengenai materi dan metodenya. Pendidikan santri akan menjadi bekal untuk berdakwah dalam masyarakat nantinya. Kebutuhan para santri terhadap penguasaan materi-materi pelajaran, metode-metode dalam mengajar, sampai pendekatan-pendekatannya di dalam masyarakat hanya akan didapatkan melalui pendidikan pesantren yang baik, 
disamping pengetahuan dasar agama yang berupa landasan syariat, akidah dan akhlaq. Berdasarkan uraian masalah di atas, maka peneliti mengangkat sebuah judul "pengembangan dan evaluasi kurikulum pendidikan di pondok pesantren desa Ganjaran Gondanglegi Malang".

\section{Rumusan Masalah}

Rumusan masalahnya yaitu:

1. Bagaimanakah pengembangan kurikulum pendidikan agama Islam di pondok pesantren desa Ganjaran Gondanglegi Malang?.

2. Bagaimanakah evaluasi kurikulum pendidikan agama Islam di pondok pesantren desa Ganjaran Gondanglegi Malang?.

\section{Tujuan Penelitian}

Tujuan penelitian ini yaitu:

1. Untuk mendeskripsikan pengembangan kurikulum pendidikan agama Islam di pondok pesantren desa Ganjaran Gondanglegi Malang.

2. Untuk mendeskripsikan evaluasi kurikulum pendidikan agama Islam di

\section{Signifikansi} pondok pesantren desa Ganjaran Gondanglegi Malang.

Signifikansi penelitian ini yaitu:

1. Penelitian ini dapat memberikan kontribusi terhadap perkembangan ilmu pengetahuan karena yang diteliti tentang ilmu pengetahuan yang sedang berkembang.

2. Hasil penelitian dapat membantu para pengasuh pondok pesantren untuk memformulasikan kebijakan baru demi perbaikan dan pengembangan pondok pesantren.

\section{Konstribusi Secara Teoritis}

Dapat dijadikan dasar sebagai pembanding penelitian lain yang sejenis yang akan diteliti.

Model yang ditemukan dalam penelitian ini dapat dijadikan dasar acuan untuk membangun ilmu pengetahuan.

Penelitian ini diharapkan memberikan kontribusi ilmu, terutama dalam hal pengembangan dan evaluasi kurikulum pendidikan di pondok pesantren.

\section{Konstribusi Secara Praktis}

Pengembangan dan evaluasi kurikulum pendidikan di pondok pesantren desa Ganjaran Gondanglegi Malang, dapat dijadikan dasar para pengasuh maupun pengelola pondok pesantren.

Hasil dari penelitian ini dapat dijadikan sebagai masukan bagi pengasuh dan pengelola pondok pesantren, untuk mengembangkan kurikulun

\section{Kajian Teori}

pendidikan di pesantren.

Pengembangan kurikulum adalah seluruh proses pengembangan kurikulum atau perbaikan dari kurikulum yang sudah ada (Hanun Asrohah dan Anas Amin Alamsyah, 2013, p.58).

Berikut ini adalah beberapa karakteristik dalam pegembangan kurikulum:

1. Rencana kurikulum harus dikembangkan dengan tujuan yang jelas.

2. Suatu program yang dilaksanakan merupakan bagian dari kurikulum yang dirancang selaras dengan prosedur pengembanagan kurikulum. 
3. Rencana kurikulum yang baik dapat menghasilkan terjadinya proses belajar yang baik.

4. Rencana kurikulum harus mengenalkan dan mendorong diversitas di antara para pelajar.

5. Rencana kurikulum harus menyiapkan semua aspek situasi belajar mengajar, seperti tujuan, penjadwalan, dan fasilitas yang menunjang.

6. Rencana kurikulum harus dikembangkan sesuai dengan karakteristik siswa/santri.

7. Pendekatan kurikulum yang banyak digunakan.

8. Rencana kurikulum harus memberikan fleksibilitas untuk memungkinkan terjadinya perencanaan guru-siswa.

9. Rencana kurikulum harus memberikan fleksibilitas untuk memungkinkan masuknya ide-ide spontan.

10.Rencana kurikulum sebaiknya merefleksikan keseimbangan antara kognitif, afektif, dan psikomotorik (Oemar Hamalik, 2011, p.185).

Dalam garis besarnya kurikulum pendidikan di pondok pesantren dapat dikembangkan melalui tahap-tahap sebagai berikut yaitu:

1. Melakukan kajian kebutuhan untuk memperoleh faktor-faktor penentu kurikulum serta latar belakangnya.

2. Menentukan bahan ajar yang akan diajarkan.

3. Merumuskan tujuan pembelajaran.

4. Menentukan hasil belajar yang diharapkan dari siswa/santri dalam tiap mata pelajaran.

5. Menentukan topik-topik tiap-tiap mata pelajaran.

6. Menentukan syarat-syarat yang dituntut dari siswa/santri

7. Menentukan bahan yang harus dibaca siswa/santri

8. Menentukan strategi mengajar yang serasi serta menyediakan berbagai sumber/alat peraga proses belajar mengajar.

9. Menentukan alat evaluasi hasil belajar siswa/santri serta skala penilaiannya.

10.Membuat rancangan rencana penilaian kurikulum secara keseluruhan dan strategi perbaikannya (M. Sulthon Masyhud dan Moh. Khusnurdilo, 2013, p.81).

Kompetensi guru adalah kemampuan dan kewenangan guru dalam melaksanakan profesinya (Muhibbin Syah, 2013, p.256). Mengingat tugas dan tanggung jawab guru yang begitu kompleksnya dalam mengembangkan kurikulum pndidikan di pondok pesantren, maka seorang guru dituntut untuk memiliki beberapa kompetensi khusus yaitu:

1) Kompetensi pedagogik

2) Kompetensi kepribadian

3) Kompetensi profesional

4) Kompetensi sosial.

Undang-undang Republik Indonesia No.14 tentang guru dan dosen menjelaskan:

1. Kompetensi pedagogik adalah kemampuan guru dalam pengelolaan pembelajaran peserta didik yang sekurang-kurangnya meliputi: 

a) Pemahaman wawasan atau landasan kependidikan,
b) Pemahaman terhadap peserta didik,
c) Pengembangan kurikulum atau silabus,
d) Perencanaan pembelajaran,
e) Pelaksanaan pembelajaran yang mendidik dan dialogis,
f) Pemanfaatan teknologi pembelajaran,
g) Evaluasi hasil balajar,
h) Pengembangan peserta didik untuk mengaktualisasikan berbagai potensi yang dimilikinya.

2. Kompetensi kepribadian adalah kemampuan kepribadian yang sekurangkurangnya mencakup kepribadian yang:
a) Beriman dan bertakwa
b) Berakhlak mulia
c) Arif dan bijaksana
d) Demokratis
e) Mantap
f) Berwibawa
g) Stabil
h) Dewasa
i) Jujur
j) Sportif
k) Menjadi teladan bagi peserta didik dan masyarakat
1) Secara obyektif mengevaluasi kinerja sendiri
m) Mengembangkan diri secara mandiri dan berkelanjutan.

3. Kompetensi profesional adalah kemampuan guru dalam menguasai pengetahuan bidang ilmu pengetahuan, teknologi, dan/atau seni dan budaya yang diampunya yang sekurang-kurangnya meliputi penguasaan:

a) Materi pembelajaran secara luas dan mendalam sesuai dengan standar isi program satuan pendidikan, mata pelajaran, dan/atau kelompok mata pelajaran yang akan diampu.

b) Konsep dan metode disiplin keilmuan, teknologi atau seni yang relevan, yang secara konseptual menaungi atau koheren dengan program satuan pendidikan, mata pelajaran, dan/atau kelompok mata pelajaran yang akan diampu.

4. Kompetensi sosial adalah kemampuan guru sebagai bagian dari masyarakat yang sekurang-kurangnya meliputi kompetensi untuk:

a) Berkomunikasi lisan, tulis, dan/atau isyarat secara santun,

b) Menggunakan teknologi komunikasi dan informasi secara fungsional,

c) Bergaul secara efektif dengan peserta didik, sesama pendidik, tenaga kependidikan, pimpinan satuan pendidikan, orang tua/wali peserta didik,

d)Bergaul secara efektif dengan masyarakat sekitar dengan mengindahkan norma serta sistem nilai yang berlaku,

e) Menerapkan prinsip persaudaraan sejati dan semangat kebersamaan. Perencanaan kurikulum adalah suatu proses ketika peserta dalam banyak tingkatan membuat keputusan tentang tujuan belajar, cara 
mencapai tujuan tersebut melalui situasi belajar mengajar, serta penelaahan keefektifan dan kebermaknaan metode tersebut. Tanpa perencanaan kurikulum, sistematika berbagai pengalaman belajar tidak akan saling berhubungan dan tidak mengarah pada tujuan yang diharapkan. Semua jenis perencanaan kurikulum terjadi pada semua tingkat pendidikan dan disesuaikan dengan tingkat kelas.

Secara umum, sebuah perencanaan kurikulum yang realitas disusun berdasarkan prinsip-prinsip sebagai berikut yaitu:

1. Perencanaan kurikulum berkenaan denagn pengalaman para santri

2. Perencanaan kurikulum dibuat berdasarkan berbagai keputusan tentang konten/proses

3. Perencanaan kurikulum mengandung keputusan-keputusan berdasarkan isu dan topik

4. Perencanaan kurikulum melibatkan banyak kelompok

5. Perencanaan kurikulum dilaksanakan pada berbagai tingkatan

6. Perencanaan kurikulum adalah sebuah proses yang berkelanjutan (Oemar Hamalik, 2011, p.172).

Taylor berpendapat bahwa evaluasi kurikulum minimal terjadi dua kali, yaitu pada awal dan akhir pengembangan kurikulum, agar dapat mengukur perubahan dalam jangka waktu tersebut. Namun, ia juga berpedapat bahwa hal ini harus dilaksanakan berturut-turut sepanjang pengembangan kurikulum. Pengembangan kurikulum adalah proses yang meliputi kegiatan untuk melaksanakan percobaan evaluasi, sehingga kekurangan yang ditemukan dapat diperbaiki untuk hasil yang lebih baik. Evaluasi terhadap penyusunan dan perancangan kurikulum sangat sulit dan rumit, serta tidak memiliki kriteria yang sama (Oemar Hamalik, 2011, p.253).

Prinsip-prinsip evaluasi kurikulum adalah sebagai berikut:

1. Tujuan tertentu, artinya setiap program evaluasi kurikulum terarah dalam mencapai tujuan yang telah ditentukan secara jelas dan spesifik. Tujuantujuan itu pula yang mengarahkan berbagai kegiatan dalam proses pelaksanaan evaluasi kurikulum.

2. Bersifat objektif, dalam artian berpijak pada keadaan yang sebenarnya, bersumber dari data yang nyata dan akurat, yang diperoleh melalui instrumen yang andal.

3. Bersifat komprehensif, mencakup semua dimensi atau aspek yang terdapat dalam ruang lingkup kurikulum. Seluruh komponen kurikulum harus mendapat perhatian dan pertimbangan secara seksama sebelum dilakukan pengambilan keputusan.

4. Kooperatif dan bertanggung jawab dalam perencanaan. Pelaksanaan dan keberhasilan suatu program evaluasi kurikulum merupakan tanggung jawab bersama pihak-pihak yang terlibat dalam proses pendidikan seperti guru, kepala sekolah, orang tua, bahkan siswa/santri itu sendiri, di samping merupakan tanggung jawab utama lembaga penelitian dan pengembangan.

5. Efisien, khususnya dalam penggunaan waktu, biaya, tenaga, dan peralatan yang menjadi unsur penunjang. Oleh karen itu, harus diupayakan agar 
hasil evaluasi lebih tinggi, atau paling tidak berimbang dengan materiil yang digunakan.

6. Berkesinambungan. Hal ini diperlukan mengingat tuntutan dari dalam dan luar sistem sekolah, yang meminta diadakannya perbaikan kurikulum. Untuk itu, peran guru dan kepala sekolah sangatlah penting, karena mereka yang paling mengetahui pelaksanaan, permasalahan, dan keberhasilan kurikulum (Oemar Hamalik, 2011, p.256).

Evaluasi kurikulum pendidikan di pondok pesantren harus diadakan untuk pengembangan kurikulum pendidikan. Sudah menjadi tanggung jawab kepala pondok untuk mewujudkan pengajar yang kompeten, yaitu dengan kriteria mampu menciptakan pengalaman belajar santri yang menyenangkan dan terus memantau perkembangan dan kebutuhan santri. Kegiatan belajar yang lebih bermakna dan berkesan bagi santri menyebabkan hasil belajar menjadi optimal.

Evaluasi kurikulum pendidikan meliputi hal-hal sebagai berikut:

1. Menilai prestasi santri untuk kepentingan pengajaran:

2. Mengkaji konsep dasar penilaian,

3. Mengkaji berbagai teknik penilaian,

4. Menyusun alat penilaian,

5. Mengkaji cara mengolah dan menafsirkan data untuk menetapkan taraf pencapaian santri,

6. Dapat menyelenggarakan penilaian pencapaian santri.

1. Menyelenggarakan penilaian untuk perbaikan proses belajar mengajar,

2. Dapat memanfaatkan hasil penilaian untuk perbaikan proses belajar mengajar.

3. Evaluasi atau penilaian secara bertahap dan berkesinambungan, dan bersifat terbuka. Dari evaluasi ini dapat diperoleh keterangan mengenai kegiatan dan kemajuan belajar santri, dan pelaksanaan kurikulum oleh guru dan tenaga kependidikan lainnya. Dalam pelaksanaan evaluasi ini, terdapat banyak instrumen pengukuran yang dapat dipergunakan oleh pendidik antara lain:

4. Tes standar

5. Tes buatan guru

6. Sampel hasil karya

7. Tes lisan

8. Observasi sistematis

9. Wawancara

10.Kuesioner

11.Daftar cek dan skala penilaian

12.Kalkulator anekdotal

13.Sosiogram dan pelaporan (Oemar Hamalik, 2011, p.180).

\section{Kontekstualisasi Teori dalam Riset}

Sejarah perkembangan pesantren, ada dua versi pendapat mengenai asal usul dan latar belakang berdirinya pesantren di Indonesia yaitu:

1. Pendapat yang menyebutkan bahwa pesantren berakar pada tradisi Islam sendiri, yaitu tarekat. Pesantren mempunyai kaitan yang erat dengan 
tempat pendidikan yang khas bagi kaum sufi. Pendapat ini berdasarkan fakta bahwa penyiaran Islam di Indonesia pada awalnya lebih banyak dikenal dalam bentuk kegiatan tarekat. Hal ini ditandai oleh terbentuknya kelompok organisasi tarekat yang melaksanakan amalan-amalan zikir dan wirid tertentu. Pemimpin tarekat yang disebut Kiai itu mewajibkan pengikutnya untuk melaksanakan suluk dengan cara tinggal bersama dengan sesama anggota tarekat dalam sebuah masjid untuk melaksanakan ibadah-ibadah dibawah bimbingan Kiai. Untuk keperluan suluk ini para Kiai menyediakan ruangan khusus untuk penginapan dan tempat-tempat khusus yang terdapat di kiri kanan masjid. Di samping mengajarkan amalan-amalan tarekat, para pengikut itu juga diajarkan agama dalam berbagai cabang ilmu pengetahuaan agama Islam. Aktifitas yang dilakukan oleh pengikut-pengikut tarekat ini kemudian dinamakan pengajian. Dalam perkembangan selanjutnya lembaga pengajian ini tumbuh dan berkembang menjadi lembaga pesantren.

2. Pesantren yang kita kenal sekarang ini pada mulanya merupakan pengambil alihan dari sistem pesantren yang diadakan oleh orang-orang Hindu di Nusantara. Kesimpulan ini berdasarkan fakta bahwa jauh sebelum datangnya Islam ke Indonesia lembaga pesantren sudah ada di negeri ini. Pendirian pesantren pada masa itu dimaksudkan sebagai tempat mengajarkan agama Hindu dan tempat membina kader. Anggapan lain mempercayai bahwa pesantren bukan berasal dari tradisi Islam alasannya adalah tidak ditemukannya lembaga pesantren di negaranegara Islam lainnya, sementara lembaga yang serupa dengan pesanteren banyak ditemukan dalam masyarakat Hindu dan Budha, seperti di India, Myanmar dan Thailand.

Pesantren di Indonesia baru diketahui keberadaan dan perkembangannya setelah abad ke 16. Pesantren-pesantren besar yang mengajarkan berbagai kitab Islam klasik dalam bidang fikih, teologi dan tasawuf. Pesantren ini kemudian menjadi pusat-pusat penyiaran Islam. Dalam catatan sejarah, Pondok pesantren dikenal di Indonesia sejak zaman Walisongo. Ketika itu Sunan Ampel mendirikan sebuah padepokan di Ampel Surabaya dan menjadikannya pusat pendidikan di Jawa. Para santri yang berasal dari pulau Jawa datang untuk menuntut ilmu agama. Bahkan di antara para santri ada yang berasal dari Gowa dan Talo, Sulawesi. Pesantren Ampel merupakan cikal bakal berdirinya pesantren-pesantren di Tanah Air. Sebab para santri setelah menyelesaikan studinya merasa berkewajiban mengamalkan ilmunya di daerahnya masing-masing. Pesantren sebagai komunitas dan sebagai lembaga pendidikan yang besar jumlahnya dan luas penyebarannya diberbagai pelosok tanah air telah banyak memberikan saham dalam pembentukan manusia Indonesia yang relegiyus (Ahmad Tafsir, 2014, p.191).

Kesederhanaan pesantren dahulu sangat terlihat, baik segi fisik bangunan, metode, bahan kajian dan perangkat belajar lainnya. Hal itu dilatarbelakangi kondisi masyarakat dan ekonomi yang ada pada waktu itu. Yang menjadi ciri khas dari lembaga ini adalah rasa keikhlasan yang dimiliki para santri dan sang Kiai. Hubungan mereka tidak hanya sekedar sebagai murid dan guru, tapi lebih seperti 
anak dan orang tua. Tidak heran bila santri merasa kerasan tinggal di pesantren walau dengan segala kesederhanaannya. Bentuk keikhlasan itu terlihat dengan tidak dipungutnya sejumlah bayaran tertentu dari para santri, mereka bersamasama bertani atau berdagang dan hasilnya dipergunakan untuk kebutuhan hidup mereka dan pembiayaan fisik lembaga, seperti lampu, bangku belajar, tinta, tikar dan lain sebagainya. Keunggulan utama pada pendidikan pesantren adalah penanaman keimanan (Ahmad Tafsir, 2014, p.203).

Umumnya, suatu pondok pesantren berawal dari adanya seorang Kiai di suatu tempat, kemudian datang santri yang ingin belajar agama kepadanya. Setelah semakin hari semakin banyak santri yang datang, timbullah inisiatif untuk mendirikan pondok atau asrama di samping rumah Kiai. Pada zaman dahulu Kiai tidak merencanakan bagaimana membangun pondoknya itu, namun yang terpikir hanyalah bagaimana mengajarkan ilmu agama supaya dapat dipahami dan dimengerti oleh santri. Kiai saat itu belum memberikan perhatian terhadap tempattempat yang didiami oleh para santri, yang umumnya sangat kecil dan sederhana. Mereka menempati sebuah gedung atau rumah kecil yang mereka dirikan sendiri di sekitar rumah Kiai. Semakin banyak jumlah santri, semakin bertambah pula gubug yang didirikan. Para santri selanjutnya memopulerkan keberadaan pondok pesantren tersebut, sehingga menjadi terkenal ke mana-mana, contohnya seperti pada pondok-pondok yang ada di desa Ganjaran Gondanglegi Malang.

Pesantren adalah lembaga pendidikan Islam yang tertua di Indoesia, setelah rumah tangga. Bila orang menulis tentang pesantren maka topik-topik yang harus ditulis sekurang-kurangnya adalah:

1. Kiai pesantren, mungkin mencakup ideal Kiai untuk zaman kini dan nanti,

2. Pondok, akan mencakup syarat-yarat fisik dan nonfisik, pembiayaan, tempat, penjagaan dan lain-lain,

3. Masjid, cakupannya akan sama dengan pondok,

4. Santri, melingkupi masalah syarat, sifat dan tugas santri,

5. Kitab kuning, bila diluaskan akan mencakup kurikulum pesantren dalam arti yang luas (Ahmad Tafsir, 2014, p.191).

Tujuan pendidikan pesantren, antara lain sebagai berikut yaitu:

1. Memiliki kebijaksanaan menurut ajaran Islam. Anak didik dibantu agar mampu memahami makna hidup, keberadaan, peranan, serta tanggung jawabnya dalam kehidupan di masyarakat.

2. Memiliki kebebasan yang terpimpin. Setiap manusia memiliki kebebasan, tetapi kebebasan itu harus dibatasi karena kebebasan memiliki potensi anarkisme.

3. Berkemampuan mengatur diri sendiri. Di pesantren, santri mengatur sendiri kehidupannya menuruti batasan yang diajarkan agama.

4. Memiliki rasa kebersamaan yang tinggi. Dalam pesantren berlaku prinsip: dalam hal kewajiban, individu harus menunaikan kewajiban lebih dahulu, sedangkan dalam hal hak, individu harus mendahulukan kepentingan orang lain sebelum kepentingan diri sendiri. 
5. Menghormati orang tua dan guru. Ini memang ajaran agama. Tujuan ini tercapai antara lain melalui penegakan berbagai pranata di pesantren seperti mencium tangan guru, tidak membantah guru.

6. Cinta kepada ilmu. Menurut al-Qur'an ilmu datang dari Allah. Banyak hadits yang mengajarkan pentingnya menuntut ilmu dan menjaganya. Karena itu orang-orang pesantren cenderung memandang ilmu sebagai sesuatu yang suci dan tinggi.

7. Mandiri. Jika mengatur diri sendiri kita sebut otonomi, maka mandiri yang dimaksud adalah berdiri atas kekuatan sendiri. Sejak awal santri telah dilatih untuk mandiri.

8. Kesederhanaan. Dilihat secara lahiriah sederhana memang mirip dengan miskin. Padahal yang dimaksud sedehana yang di pesantren adalah sikap hidup, yaitu memandang sesuatu, terutama materi, secara wajar, proporsional, dan fungsional. Sebenarnya banyak santri yang berlatar belakang orang kaya, tetapi mereka dilatih hidup sederhana (Ahmad Tafsir, 2014, p.202).

Setiap lembaga pendidikan, termasuk pesantren dituntun untuk memberikan pelayanan sebaik mungkin kepada pelanggannya. Agar dapat melakukan hal tersebut dengan baik, pesantren perlu dukungan sistem manajemen yang baik. Beberapa ciri sistem manajemen yang baik adalah pola pikir yang teratur, pelaksanaan kegiatan yang teratur, dan penyikapan terhadap tugas-tugas kegiatan secara baik (M. Sulthon Masyhud dan Moh. Khusnurdilo, 2003, p.23).

Secara umum pesantren berfungsi sebagai komunitas dan lembaga pendidikan yang besar jumlahnya dan tersebar di berbagai pelosok tanah air yang telah banyak memberikan kontribusi dalam membentuk manusia Indonesia yang religius. Dilihat secara historis, pesantren memiliki pengalaman luar biasa dalam membina, mencerdaskan, dan mengembangkan masyarakat. Bahkan, pesantren mampu meningkatkan perannya secara mandiri dengan menggali potensi yang dimiliki masyarakat di sekelilingnya. Pondok pesantren adalah suatu lembaga pendidikan agama Islam yang tumbuh serta diakui oleh masyarakat sekitarnya, dengan sistem asrama yang santri-santrinya menerima pendidikan agama melalui sistem pengajaran atau madrasah yang sepenuhnya berada di bawah kedaulatan dan kepemimpinan (leadership) seseorang atau beberapa orang Kiai dengan ciriciri khas yang bersifat kharismatik serta indenpenden dalam segala hal.

Aktivitas belajar santri adalah aktivitas kejasmanian maupun aktivitas mental. Aktivitas belajar santri dapat digolongkan dalam beberapa hal yaitu: aktivitas visual (visual activities) seperti membaca, menulis, melakukan eksperimen, dan demonstrasi, aktivitas lisan (oral activities) seperti berpidato, qiro'ati, sajak, tanya jawab, diskusi, aktivitas mendengarkan (listening activities) seperti mendengar penjelasan pengajar, ceramah, pengarahan, aktivitas gerak (motor activities) seperti senam santri, atletik, melukis, menggambar dan aktivitas menulis (writting activities) seperti mengarang, membuat makalah, membuat surat, menulis arab indah (kaligrafi). Setiap jenis aktivitas tersebut di atas memiliki kadar atau bobot yang berbeda tergantung pada segi tujuan mana yang akan dicapai dalam kegiatan belajar mengajar. Yang jelas, aktivitas kegiatan pembelajaran santri hendaknya memperoleh hasil yang maksimal. 
Arti penting dari keaktifan santri untuk mendukung keberhasilannya dalam kegiatan pembelajaran itulah yang menjadi dasar diterapkannya pendekatan Active Learning dalam pembelajaran. Pendekatan ini diasumsikan pada prinsipprinsipnya antara lain:

1) Pembelajaran hanya bisa terjadi jika santri terlibat secara aktif,

2) Setiap santri memiliki potensi untuk bisa dikembangkan,

3) Peran pengajar lebih sebagai fasilatator pembelajaran.

Dari pernyataan pertama dipahami bahwa meskipun santri hadir di ruang kelas, bisa terjadi dia tidak belajar karena dia hanya menjadi pihak yang pasif. Pernyataan kedua memberi tahu pengajar agar memberi dorongan kepada santri untuk mengembangkan potensi-potensi yang dimilikinya melalui diskusi, prestasi, peragaan dan sebagainya. Sedangkan pernyataan ketiga menjelaskan bahwa pada masa sekarang ini tidak mengikuti banking concept yang mengandaikan santri ibarat tabung kosong yang hanya pasif, karena yang terpenting pembelajaran berpusat pada santri. Santri didorong untuk bisa memperoleh pengetahuan dengan caranya sendiri. Dengan demikian tumbuh kemampuan dan kecintaannya pada kegiatan belajar.

\section{Metode Penelitian}

\section{Pendekatan dan Jenis Penelitian}

Kehadiran dan keterlibatan peneliti di pondok pesantren desa Ganjaran Gondanglegi Malang hal yang sangat diperlukan dalam penelitian kualitatif, karena peneliti bertindak sekaligus sebagai instrumen pengumpulan data. Instrumen dalam penelitian ini adalah peneliti sendiri, dan subjeknya adalah orang yang diwawancarai dalam situasi tertentu. Keperluan peneliti untuk hadir di pondok pesantren desa Ganjaran Gondanglegi Malang yaitu untuk mencari datadata yang terkait dengan rumusan masalah.

Peneliti bertindak sebagai instrumen, maka dari itu diharapkan adanya hubungan baik dengan orang-orang yang akan dijadikan sumber penelitian. Pada penelitian ini peneliti akan melihat dan memantau langsung kegiatan yang berkaitan dengan penelitian, bentuk partisipasi secara aktif yakni mengikuti kegiatan yang dijalankan, hal ini dimaksudkan untuk menciptakan hubungan yang baik dan saling mempercayai. Dalam proses pengumpulan data, peneliti menjadi instrumen kunci. Peneliti mengadakan pengamatan dan menemui para informan, karena hal ini sangat diutamakan dalam kondisi dan situasi yang sesungguhnya. Oleh karena itu, kehadiran peneliti di sini yang bertindak sebagai pengamat partisipan diketahui sepenuhnya oleh informan.

Penelitian ini menggunakan pendekatan kualitatif. Penelitian kualitatif ini penekanan pada penggunaan yang bukan berupa angka (matematika) khususnya dalam proses analisis data hingga dihasilkan temuan penelitian secara alamiah. Penelitian ini menggunakan jenis Field Research (penelitian lapangan), dan kualitatif sebagai pendekatannya, karena yang akan diteliti adalah menyangkut masalah kurikulum dan evaluasi pendidikan agama Islam di pondok pesantren desa ganjaran gondanglegi Malang. "Dalam penelitian kualitatif, seorang peneliti tidak diharapkan dan tidak dianjurkan memelihara asumsi dan keyakinan bahwa dirinya sangat tahu tentang fenomena yang berhak dikaji” (Burhan Bungin, 2013, p.48). 


\section{Metode Pengumpulan Data}

Agar mendapatkan data yang benar-benar valid dalam penelitian ini, maka peneliti perlu menentukan metode pengumpulan data yang sesuai. Oleh karena itu, peneliti menggunakan metode-metode sebagai berikut:

\section{Metode Wawancara}

"Wawancara adalah bentuk komunikasi antara dua orang, melibatkan seseorang yang ingin memperoleh informasi dari seorang yang lainnya dengan mengajukan pertanyaan-pertanyaan, berdasarkan tujuan tertentu. Wawancara secara garis besar dibagi dua, yakni wawancara tak terstruktur dan wawancara terstruktur" (Masykuri Bakri, 2016, p.153). Peneliti menggunakan jenis pedoman wawancara tak tersruktur, karena susunan pertanyaannya dan susunan kata-kata dalam setiap pertanyaan dapat diubah pada saat wawancara di pondok pesantren desa Ganjaran Gondanglegi Malang, disesuaikan dengan kebutuhan dan kondisi saat wawancara di pondok pesantren tersebut, termasuk usia dan tingkat pendidikan informan yang dihadapi. Peneliti berusaha mengumpulkan informasi dengan cara mengajukan pertanyaan secara lisan. Untuk dijawab secara lisan pula, secara langsung dengan tatap muka antara peneliti sendiri dengan sumber informasi atau informan dan dilaksanakan secara sistematis.

\section{Metode Observasi Partisipan}

"Observasi partisipan adalah yang paling komprehensif dari semua tipe strategi penelitian. Dengan observasi partisipan ini peneliti dapat memahami lebih dalam tentang fenomena (perilaku atau peristiwa) yang terjadi di lapangan" (Rulam Ahmadi, 2015, p.102). Observasi sebagai teknik pengumpulan data mempunyai ciri yang spesifik bila dibandingkan dengan teknik wawancara. Kalau wawancara selalu berkomunikasi dengan informan penelitian, maka observasi tidak terbatas pada orang, tetapi juga objek-objek alam yang terkait dengan masalah kurikulum dan evaluasi pendidikan agama Islam di pondok pesantren desa Ganjaran Gondanglegi Malang.

\section{Metode Dokumentasi}

"Dokumentasi adalah mengacu pada material (bahan) seperti fotografi, vidio, usulan, kode etik, buku tahunan, dan sejenisnya yang dapat digunakan sebagai informasi suplemen sebagai bagian dari kajian kasus" (Rulam Ahmadi, 2015, p.114). Peneliti mengumpulkan data atau laporan tertulis dari semua peristiwa yang isinya berupa penjelasan dan penilaian terhadap objek yang diteliti, terkait dengan masalah pengembangan dan evaluasi kurikulum pendidikan agama Islam di pondok pesantren desa Ganjaran Gondanglegi Malang.

\section{Teknik Analisis Data}

"Analisis data adalah proses mengatur urutan data, mengorganisasikan ke dalam suatu pola, kategori dan satuan uraian dasar. Dan penafsiran adalah memberikan arti signifikan terhadap analisis, menjelaskan pola uraian dan mencari hubungan di antara dimensi-dimensi uraian" (Lexy J Moleong, 2015, p.103). Analisis data dapat didefinisikan sebagai proses penelaahan, pengurutan, dan pengelompokan data dengan tujuan untuk menyusun hipotesis kerja dan mengangkatnya menjadi kesimpulan atau teori sebagai temuan penelitian. 


\section{Hasil Penelitian}

Hasil penelitian yaitu sebagai berikut:

1. Pengembangan kurikulum pendidikan agama Islam di pondok pesantren desa Ganjaran Gondanglegi Malang yaitu sebagai berikut:

a. Pengembangan kurikulum pendidikan agama Islam di Pondok Pesantren Mansyaul Ulum desa Ganjaran Gondanglegi Malang ialah dengan cara rencana kurikulum dikembangkan dengan tujuan yang jelas, menyiapkan jadwal pelajaran, dan rencana kurikulum dikembangkan sesuai dengan karakteristik santri.

b. Pengembangan kurikulum pendidikan agama Islam di Pondok Pesantren Miftahul Ulum desa Ganjaran Gondanglegi Malang ialah dengan cara menentukan bahan ajar yang akan diajarkan, menentukan bahan yang harus dibaca santri, menentukan strategi mengajar yang serasi, menyediakan sumber proses belajar mengajar, menyiapkan jadwal pelajaran, dan menyiapkan calon guru.

c. Pengembangan kurikulum pendidikan agama Islam di Pondok Pesantren al-Mubarok desa Ganjaran Gondanglegi Malang ialah dengan cara rencana kurikulum dikembangkan dengan tujuan yang jelas, menyiapkan jadwal pelajaran, dan rencana kurikulum dikembangkan sesuai dengan karakteristik santri, menyiapkan calon guru, dan penerapan kurikulum pendidikan di Pondok Pesantren alMubarok sangat dipengaruhi oleh kemampuan pengajar.

d. Pengembangan kurikulum pendidikan agama Islam di Pondok Pesantren Assanamiyah desa Ganjaran Gondanglegi Malang ialah dengan cara menentukan bahan ajar yang akan diajarkan, menyediakan sumber proses belajar mengajar, dan menyiapkan calon guru pendidikan agama Islam yang kompoten di bidangnya.

e. Pengembangan kurikulum pendidikan agama Islam di Pondok Pesantren Tahfidhul Qur'an desa Ganjaran Gondanglegi Malang ialah dengan cara rencana kurikulum dikembangkan dengan tujuan yang jelas, menyiapkan jadwal pelajaran, dan rencana kurikulum dikembangkan sesuai dengan karakteristik santri, menentukan bahan ajar yang akan diajarkan, dan menyediakan sumber proses belajar mengajar.

f. Pengembangan kurikulum pendidikan agama Islam di Pondok Pesantren Hikmatul Hasanah desa Ganjaran Gondanglegi Malang ialah dengan cara menentukan bahan ajar yang akan diajarkan, menentukan strategi mengajar yang serasi, menyediakan sumber proses belajar mengajar, menyiapkan jadwal pelajaran, dan menyiapkan calon guru dan penerapan kurikulum pendidikan di Pondok Pesantren al-Mubarok sangat dipengaruhi oleh kemampuan pengajar.

g. Pengembangan kurikulum pendidikan agama Islam di Pondok Pesantren Raudlatul Ulum al-Bukhori desa Ganjaran Gondanglegi Malang ialah dengan cara menyiapkan jadwal pelajaran, dan rencana kurikulum dikembangkan sesuai dengan karakteristik santri, 
menyediakan sumber proses belajar mengajar, dan menyiapkan calon guru pendidikan agama Islam yang kompoten di bidangnya.

h. Pengembangan kurikulum pendidikan agama Islam di Pondok Pesantren Zainul Ulum desa Ganjaran Gondanglegi Malang ialah dengan cara menentukan bahan ajar yang akan diajarkan, menentukan bahan yang harus dibaca santri, menyediakan sumber proses belajar mengajar, menyiapkan calon guru, dan penerapan kurikulum pendidikan sangat dipengaruhi oleh kemampuan pengajar.

i. Pengembangan kurikulum pendidikan agama Islam di Pondok Pesantren Raudlatul Ulum 1 desa Ganjaran Gondanglegi Malang ialah dengan cara rencana kurikulum dikembangkan dengan tujuan yang jelas, menyiapkan jadwal pelajaran, dan menyiapkan calon guru.

j. Pengembangan kurikulum pendidikan agama Islam di Pondok Pesantren Raudlatul Mubtadi'in desa Ganjaran Gondanglegi Malang ialah dengan cara menentukan bahan ajar yang akan diajarkan, menentukan bahan yang harus dibaca santri, menentukan strategi mengajar yang serasi, menyediakan sumber proses belajar mengajar, menyiapkan jadwal pelajaran, dan menyiapkan calon guru, dan rencana kurikulum dikembangkan dengan tujuan yang jelas.

2. Evaluasi kurikulum pendidikan agama Islam di pondok pesantren desa Ganjaran Gondanglegi Malang dilaksanakan dua kali dalam pengembangan kurikulumnya. Pondok Pesantren Mansyaul Ulum desa Ganjaran telah melaksanakan evaluasi dengan menggunakan instrumen pengukuran yang berbentuk tes buatan guru dan tes lisan. Pondok Pesantren Miftahul Ulum desa Ganjaran telah melaksanakan evaluasi dengan menggunakan instrumen pengukuran yang berbentuk tes standar dan kuesioner. Pondok Pesantren al-Mubarok desa Ganjaran telah melaksanakan evaluasi dengan menggunakan instrumen pengukuran yang berbentuk tes buatan guru dan tes lisan. Pondok Pesantren Assanamiyah desa Ganjaran telah melaksanakan evaluasi dengan menggunakan instrumen pengukuran yang berbentuk tes buatan guru. Pondok Pesantren Tahfidhul Qur'an desa Ganjaran telah melaksanakan evaluasi dengan menggunakan instrumen pengukuran yang berbentuk tes buatan guru. Pondok Pesantren Hikmatul Hasanah desa Ganjaran telah melaksanakan evaluasi dengan menggunakan instrumen pengukuran yang berbentuk tes buatan guru dan tes lisan. Pondok Pesantren Raudlatul Ulum al-Bukhori desa Ganjaran telah melaksanakan evaluasi dengan menggunakan instrumen pengukuran yang berbentuk tes buatan guru. Pondok Pesantren Zainul Ulum desa Ganjaran telah melaksanakan evaluasi dengan menggunakan instrumen pengukuran yang berbentuk tes buatan guru. Pondok Pesantren Raudlatul Ulum 1 desa Ganjaran telah melaksanakan evaluasi dengan menggunakan instrumen pengukuran yang berbentuk tes buatan guru dan tes lisan. Pondok Pesantren

Raudlatul Mubtadi'in desa Ganjaran Gondanglegi Malang telah melaksanakan evaluasi dengan menggunakan instrumen pengukuran yang berbentuk tes standar dan tes lisan. 


\section{Penutup}

Akhirnya, tiada balasan yang dapat penulis sampaikan kepada semua pihak yang telah membantu menyelesaikan karya ilmiah ini, selain ucapan Jazakumullahu Khairan katsiran. Dan saya mohon maaf atas semua kesalahan dari pribadi saya sendiri. Dan juga semuga karya ilmiah ini dapat bermanfaat bagi seluruh umat Islam di dunia dan akhirat, amin.

\section{Daftar Rujukan}

Ahmad Tafsir (2014). Ilmu Pendidikan dalam Perspektif Islam. Bandung: PT Remaja Rosdakarya.

Burhan Bungin (2013). Analisis Data Penelitian Kualitatif. Jakarta: PT Raja Grafindo Persada.

Hanun Asrohah dan Anas Amin Alamsyah (2013). Pengembangan Kurikulum. Surabaya: Kopertais IV Press.

Lexy J Moleong (2015). Metode Penelitian Kualitatif. Bandung: PT Remaja rosdakarya.

M. Sulthon Masyhud dan Moh. Khusnurdilo (2013). Manajemen Pondok Pesantren. Jakarta: Diva Pustaka.

Muhibbin Syah (2013). Psikologi Pendidikan dengan Pendekatan Baru. Bandung: PT Remaja Rosdakarya.

Oemar Hamalik (2011). Dasar Dasar Pengembangan Kurikulum. Bandung: PT Remaja rosdakarya.

Rulam Ahmadi (2015). Memahami Metodologi Penelitian Kualitatif. Malang: Universitas Negeri Malang.

Undang-undang Republik Indonesia No.14 tentang guru dan dosen (2017). Undang-Undang Tentang Guru dan Dosen. Bandung: Citra Umbara. 
Yazidul Busthomi

234 Annaba : Jurnal Pendidikan Islam 